\title{
PLANT COMMUNITY DYNAMICS AND RARE OR EXOTIC SPECIES DISTRIBUTIONS AND DYNAMICS IN CEDAR BREAKS NATIONAL MONUMENT
}

Catherine Jean and David W. Roberts

Department of Forest Resources and Ecology Center

Utah State University

Logan

\section{Objectives}

The overall objective of this research is to develop a comprehensive vegetation classification and management system for Cedar Breaks National Monument. Specific objectives are:

1. To complete an inventory of current community types, habitat types, distribution of rare of endangered plant species and the potential habitat for these same species, and the distribution and dynamics of exotic plant species found inside the Monument; and

2. To develop an ecologically-based landscape succession model to serve as a comprehensive predictive tool for use in managing the vegetation resources in Cedar Breaks National Monument.

Methods and Progress to Date

During the 1988 field season we collected 82 sample plots of data, including the coverage of all vascular plant species, the basal area of all the tree species, the age of the largest individual tree for each species, and site characteristics including elevation, aspect, slope, topographic position, soil type, fire history and other miscellaneous observations. These plots were located on topographic base maps and data on the distribution of vegetation types were recorded on the field forms. Over 200 voucher specimens were collected during the field season and have been identified. Thirteen new species were collected which were previously unknown for Cedar Breaks National Monument. Three of these are candidate species for listing as rare or endangered with the U.S. Fish and Wildlife Service.

All forested sample plots have been identified to habitat type and phase following Youngblood and Mauk (1985). The plots cover a range of habitat types from climax Abies concolor at lower elevations, climax Picea pungens, Pinus longaeve and Pinus flexilis on the break sites, up through forests of climax Abies lasiocarpa and Picea engelmannii on high elevation sites. Specifically, we identified four habitat types in the Abies concolor series, ( $\mathrm{ABCO} / \mathrm{ARPA}, \mathrm{ABCO} / \mathrm{CELE}, \mathrm{ABCO} / \mathrm{J} \mathrm{CO}$, and $\mathrm{ABCO} / \mathrm{BERE}$ ), 
the PIFL/PILO series, one habitat type in the Picea engelmannii series (PIEN/RIMO), and five habitat types in the Abies lasiocarpa series ( $\mathrm{ABLA} / \mathrm{BERE}$, ABLA/JUCO, ABLA/CARO, ABLA/RIMO, and $\overline{\mathrm{ABLA}} / \overline{\mathrm{ACCO}}$ ).

All vegetation data and some environmental variables for the 1988 field season have been coded and entered into the computer analysis software. Preliminary analysis of vegetation distribution characteristics have been performed for the forested habitat types, beginning with an ordination analysis of the primary role of elevation in determination of vegetation distribution. The forest habitat types have been checked for within-type homogeneity and between-type similarity. In some cases the habitat types are fairly similar and distinguished on subtle differences. However, similarity analysis of the individual plots within types indicates that the types are generally unique and selfcontained.

Currently the development of a preliminary community type classification and a non-forest habitat type classification is underway. A summary of the distribution of all rare or endangered plants by location, habitat and community type will follow the completion of the community type classification.

\section{Literature Cited}

Youngblood, A. P., and R. L. Mauk. 1985. Coniferous forest habitat types of central and southern Utah. USDA, Ogden, UT. Intermountain For. and Range Exp. Sta., Forest Service, Gen. Tech. Rept. INT-187. 